\title{
Allowable Torsional Eccentricity for the Simplified Method for the Seismic Analysis of Low-Rise Confined Masonry Shear-Wall Buildings of Mexican Codes
}

\author{
Arturo Tena-Colunga ${ }^{1, *}$ and Arturo López-Blancas ${ }^{2}$ \\ ${ }^{l}$ Departamento de Materiales, Universidad Autónoma Metropolitana, Azcapotzalco, Mexico City, Mexico \\ ${ }^{2}$ INPRESA, Mexico City, Mexico
}

\begin{abstract}
A parametric study devoted to assess the limiting value for the static eccentricity $\left(e_{s}\right)$ for the application of the simplified method for seismic analysis (SMSA) of bearing-wall confined masonry structures of Mexican Building Codes is presented. Based upon the results of a comprehensive parametric study, limiting values for $e_{s}$ for the use of the SMSA are proposed for three different performance levels for the structure: (a) elastic response, (b) completely nonlinear (cracked) response of all walls along the building height and, (c) partially nonlinear (cracked) response along the height. The criterion used to propose limiting values for $e_{s}$ was that the underestimation of shear forces predicted for the first story walls with the SMSA was within reasonable limits with respect to those shear forces computed with a rigorous 3D static analysis using an equivalent linearization for the nonlinear (cracked) response of the walls, in order to insure reasonably safe designs of such structures.
\end{abstract}

Keywords: Masonry structures, masonry walls, confined masonry, seismic analysis, simplified method of analysis, torsional static eccentricity.

\section{INTRODUCTION}

Low-rise masonry shear wall buildings with rigid reinforced concrete (RC) diaphragms are used extensively worldwide, particularly in Mexico [1], in most -if not allLatin-American and Caribbean countries [2-6], in some European countries like Italy, Portugal and Slovenia [3,7-9], in Asian countries like Iran, Indonesia [10], Pakistan [11] and China [9,12], and African nations like Algeria [13]. In Mexico, this structural system accounts for almost $70 \%$ of the engineered construction, as most housing and many public school projects nationwide are built using low-rise masonry structures with reinforced concrete (RC) floor systems.

Simplified methods for the seismic analysis (SMSA) of low-rise bearing walls structures are available in many building codes, but their level of complexity varies from country to country.

For example, in the United States, ASCE 7-05 [14] perhaps addresses the most detailed and complex simplified method for both rigid and flexible diaphragm structures, as described in its section 12.14. Flexible diaphragms are included because wood diaphragms, that are very flexible, are commonly used in the United States for low-rise bearing wall construction [15-19]. This simplified method is restricted to structures up to three stories in height above grade and basically it is a relatively simpler version of the static method of analysis, where equivalent static lateral forces are

*Address correspondence to this author at the Departamento de Materiales, Universidad Autónoma Metropolitana; Tel: + (52-55) 5318-9460;

Fax: + (52-55) 5318-9085; E-mail: atc@correo.azc.uam.mx applied to a linear mathematical model for the structure considered fixed at its base [14]. For structures with rigid diaphragms, the seismic design story shear shall be distributed to the various vertical resisting elements in the story under consideration based on the relative lateral stiffnesses of the vertical elements and the diaphragm. Torsional and overturning effects should be included in the analysis, but structural drift need not be calculated [14]. A maximum static eccentricity at any level shall not exceed 15 percent of the greatest width of the diaphragm parallel to that axis [14]. No information is provided in ASCE 7-05 regarding whether there are studies that support the recommended limiting value for the static eccentricity or if this value was proposed based on the experts' opinion of code committee members.

The simplified method advocated by Eurocode 8 [20] under its section 9.7 ("Rules for simple masonry buildings") basically endorses a minimum wall density depending on the type of masonry construction (unreinforced masonry, confined masonry and reinforced masonry) for building up to five stories in height. Any type of floors may be used, provided that the general requirements of continuity and effective diaphragm action are satisfied. Among other requirements, it is established that the building should be stiffened by shear walls, arranged almost symmetrically in plan in two orthogonal directions [20]. However, no recommendation is provided to limit torsional effects in terms of a maximum static eccentricity.

Simplified methods for seismic analysis in LatinAmerican seismic codes are mostly specified for the design of low-rise, squatty rigid diaphragm structures [21-24]. Perhaps the simplest method is the one proposed in the Argen- 
tinean code which endorses a minimum wall density for rigid-diaphragm buildings; however, it is restricted for buildings up to two stories or 7 meters in height [24]. The simplified method of Mexican building Codes [21,22] is perhaps the most complete yet simple method to apply in the region, as described in greater detail below.

The simplified method for seismic analysis (SMSA) allowed by Mexican Building Codes is frequently used by structural engineers in Mexico for the analysis and design of somewhat regular low-rise shear-wall structures. The SMSA allows one to design buildings up to 5 stories or 13 meters in height by just computing the seismic shear forces that each wall has to carry according to its relative shear stiffness, and then assessing if the masonry wall has enough strength to carry the acting shear force or if horizontal steel reinforcement is needed. This can be done as it is assumed in the SMSA that: a) building safety is governed by diagonal tension shear failure of its walls. Vertical reinforcement in the tie-column is assumed to provide sufficient flexural capacity and, b) the story shear capacity is the sum of the shear capacities of all walls in the direction of analysis and all the confined masonry walls are able to reach their diagonal cracking capacity before the story failure takes place. It is worth emphasizing that in the calculation of the wall shear capacity in the SMSA [21-23], when the height over length $(\mathrm{H} / \mathrm{L})$ aspect ratio of the wall exceeds 1.33 , the shear resistance must be reduced by multiplying it by $(1.33 \mathrm{~L} / \mathrm{H})^{2}$.

Once all walls are correctly designed by shear forces, the design procedure is over, as no further reviews are needed, for example, to evaluate if lateral drifts meet code requirements, etc. Therefore, the SMSA is very attractive as it allows studying quickly different options for the design of low-rise buildings with a small computational effort, as a modest computer with a spreadsheet program becomes a powerful tool to implement the SMSA.

The SMSA is based on an idealized distribution of lateral forces of symmetric shear-wall structures with rigid diaphragms (Fig. 1) and without wall rotations. Then, in elevation, under the SMSA it is assumed that any shear wall $j$ can be represented by a shear model (Fig. 2). Therefore, it can be demonstrated that, according to the SMSA, the acting shear force in any wall $j$ at level $i, V_{j i}$, is [21,22,25]:

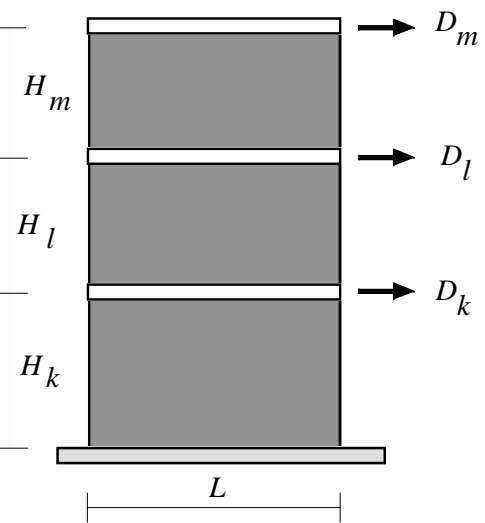

a) Solid shear wall

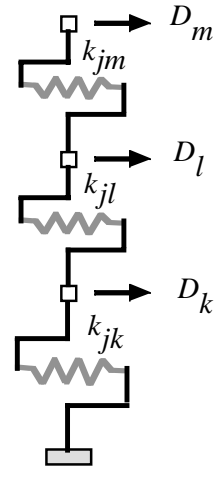

b) Shear model
Fig. (2). Shear wall modeling assumption related to the SMSA.

$$
V_{j i}=V_{i} \frac{F_{A E_{j i}} A_{T_{j i}}}{\sum_{j=1}^{n} F_{A E_{j i}} A_{T_{j i}}}
$$

where $V_{i}$ is the shear force applied at level $i, F_{A E j i}$ is the effective shear area factor of wall $j$ at level $i$ (proposed by SMSA) and $A_{T j i}$ is the cross section area (axial area) of wall $j$ at level $i$.

Low-rise masonry building must satisfy the following requirements $[21,22,25]$ in order to use the SMSA for its design: (1) the walls must carry more than $75 \%$ of the gravitational loads, (2) all walls must be connected to a rigid and strong floor diaphragm, (3) the plan aspect ratio should not exceed two $\left(L_{1} / L_{2} \leq 2\right)$, (4) the ratio between the height of the structure and the shorter plan side should not exceed 1.5 $\left(\mathrm{H}_{\mathrm{T}} / \mathrm{L}_{2} \leq 1.5\right)$, (5) the structure shall not be higher than five stories in height or 13 meters $(42.7 \mathrm{ft})$, whichever is smaller and, (6) the distribution of walls in plan must be as symmetric as possible, but some asymmetry is allowed. Therefore, a maximum static eccentricity at any level, $e_{s i}$, must not exceed
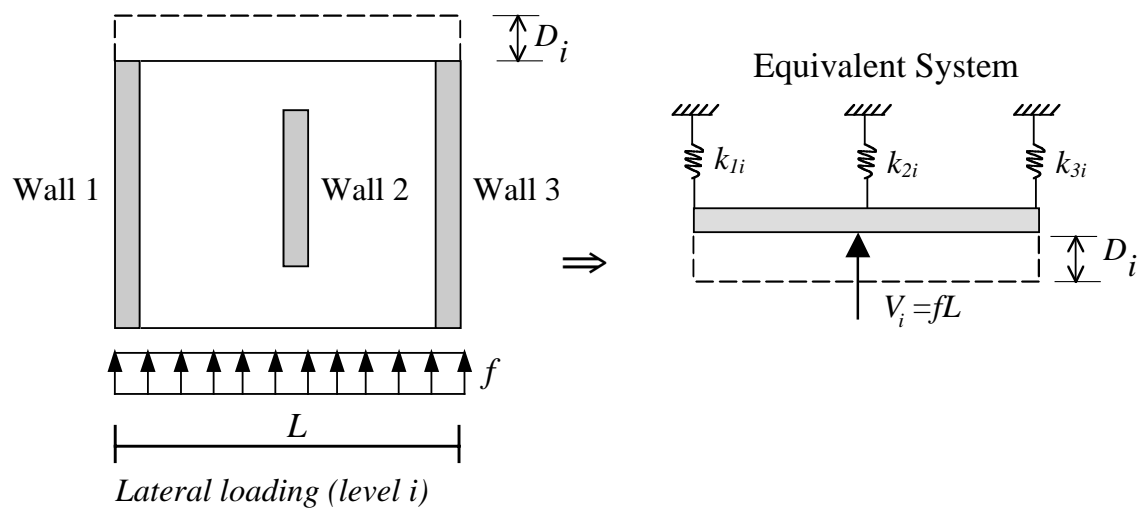

Fig. (1). Rigid diaphragm hypothesis related to the SMSA. 
ten percent of the maximum floor dimension $\left(B_{i}\right)$ perpendicular to the direction of analysis, that is, $e_{s i} \leq 0.1 B_{i}$ (Fig. 3).

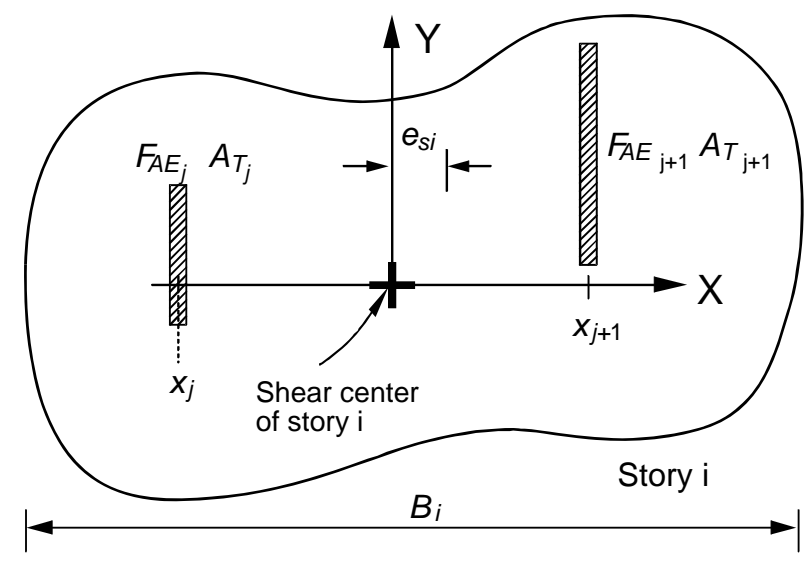

Fig. (3). Definition of static eccentricity for the SMSA of Mexican Codes (adapted from NTCM-2004 2004).

An approximate formula to compute the static torsional eccentricity $\left(e_{s i}\right)$ is proposed for the SMSA [21,22]. This formula is based on a centroid of the effective shear area for a given distribution of resisting elements as shown in Fig. (3) and is:

$$
e_{s i}=\frac{\left|\sum_{j=1}^{n} x_{j} F_{A E j} A_{T j}\right|}{\sum_{j=1}^{n} F_{A E j} A_{T j}} \leq 0.1 B_{i}
$$

The required review for compliance for a maximum static eccentricity $e_{s}$ of $10 \%$ was first introduced in the masonry regulations for the 2004 version of Mexico's Federal District Code [21,22]. This was done in order to insure that the SMSA could only be used on low-rise shear wall structures that comply with the conditions of structural regularity established in the seismic regulations of Mexico's Federal District Code [26]. However, there were no specific studies available at the times where a limiting value for $e_{s}$ was assessed for the application of the SMSA, as the $10 \%$ limiting value is the one prescribed to limit torsional responses in regular buildings, as described elsewhere [27,28]. Therefore, this review was mandatory and then, a parametric study was planned to assess the limiting value for $e_{s}$ for the application of the SMSA, as described in following sections.

\section{REVIEW AND PROPOSAL OF EFFECTIVE SHEAR AREA FACTORS FOR THE SMSA}

As reported in detail in Tena-Colunga and Cano-Licona [25] while it was being reviewed the approximations of the SMSA when compared to rigorous 3D static analysis using an equivalent linearization to model the allowable cracked response of confined masonry walls, it was found that in order to improve the accuracy of the SMSA, an in-depth review of the effective shear area factors $\left(F_{A E}\right)$ proposed by the method in NTCM-2004 was needed first.
Effective shear area factors $F_{A E}$ proposed by Mexican codes for the SMSA depend on the height over length aspect ratio of the wall (H/L), and are given by:

$$
\begin{array}{llll}
F_{A E}=1 & \text { if } & \frac{H}{L} & \leq 1.33 \\
F_{A E}=\left(1.33 \frac{L}{H}\right)^{2} & & \text { if } & \frac{H}{L}>1.33
\end{array}
$$

In order to obtain suitable new effective shear area factors, the first step was to rationalize from elastic structural analysis theory how these equations would look if one considers that multistory elastic walls can be represented by equivalent wide columns where shear deformations are included, having both translational and rotational degrees of freedom. The details of this development are presented elsewhere [29,30] and briefly summarized in Tena-Colunga and Cano-Licona [25]. From the static condensation of the assembled stiffness matrix for the walls, it was obtained that the stiffness coefficients of the resulting lateral stiffness matrix have polynomial expressions in terms of the $\mathrm{H} / \mathrm{L}$ ratio. From this derivation it was clear that simple polynomial forms in terms of $\mathrm{H} / \mathrm{L}$ could be used to improve the estimates of the SMSA to match closely those obtained from a 3D static analysis.

The review of these $F_{A E}$ and the formulation of new effective shear area factor for three different structural performance levels was based on extensive parametric studies, where the $F_{A E}$ originally proposed in the SMSA were evaluated and modified to improve the estimates of shear forces using this simple method [25,29,30]. Acting shear forces in the shear walls of symmetric buildings according to the SMSA were compared with respect to those obtained with rigorous $3 \mathrm{D}$ static analysis. The impact of shear deformations in the $3 \mathrm{D}$ distribution of the forces absorbed by these walls was assessed for different wall aspect ratios $(\mathrm{H} / \mathrm{L})$.

New effective shear area factors were proposed for three different performance levels for the structure [25,29,30]. For elastic response (Fig. 4):

$$
\begin{array}{ll}
F_{A E}=1.5+\frac{H}{L}-1.5\left(\frac{H}{L}\right)^{2} & \text { if } 0.4 \leq \frac{H}{L} \leq 1.0 \\
F_{A E}=2.2-1.5 \frac{H}{L}+0.3\left(\frac{H}{L}\right)^{2} & \text { if } 1.0<\frac{H}{L} \leq 2.5
\end{array}
$$

For partially cracked (nonlinear) response along the height (Fig. 5):

$$
F_{A E P A}=0.6+0.6\left(\frac{H}{L}\right)-0.3\left(\frac{H}{L}\right)^{2}+0.05\left(\frac{H}{L}\right)^{3} \text { if } \quad 0.4 \leq \frac{H}{L} \leq 2.5
$$

For completely cracked (nonlinear) response of all walls along the building height (Fig. 6):

$$
F_{\text {AETA }}=1+1.1\left(\frac{H}{L}\right)-0.6\left(\frac{H}{L}\right)^{2}+0.1\left(\frac{H}{L}\right)^{3} \quad \text { if } 0.4 \leq \frac{H}{L} \leq 2.5
$$

These new effective shear area factors were calibrated to reasonably estimate the acting shear forces in the first story 

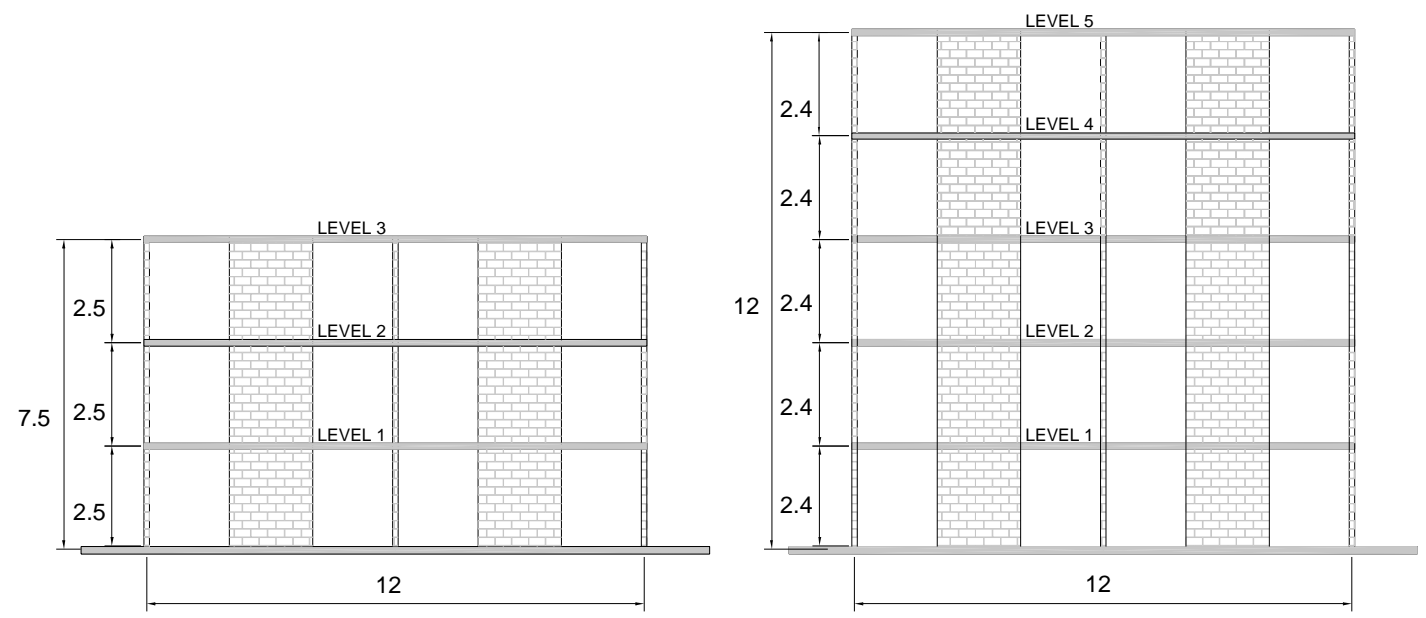

Fig. (4). Elevation of walls running in the horizontal direction for elastic response (dimensions in meters).
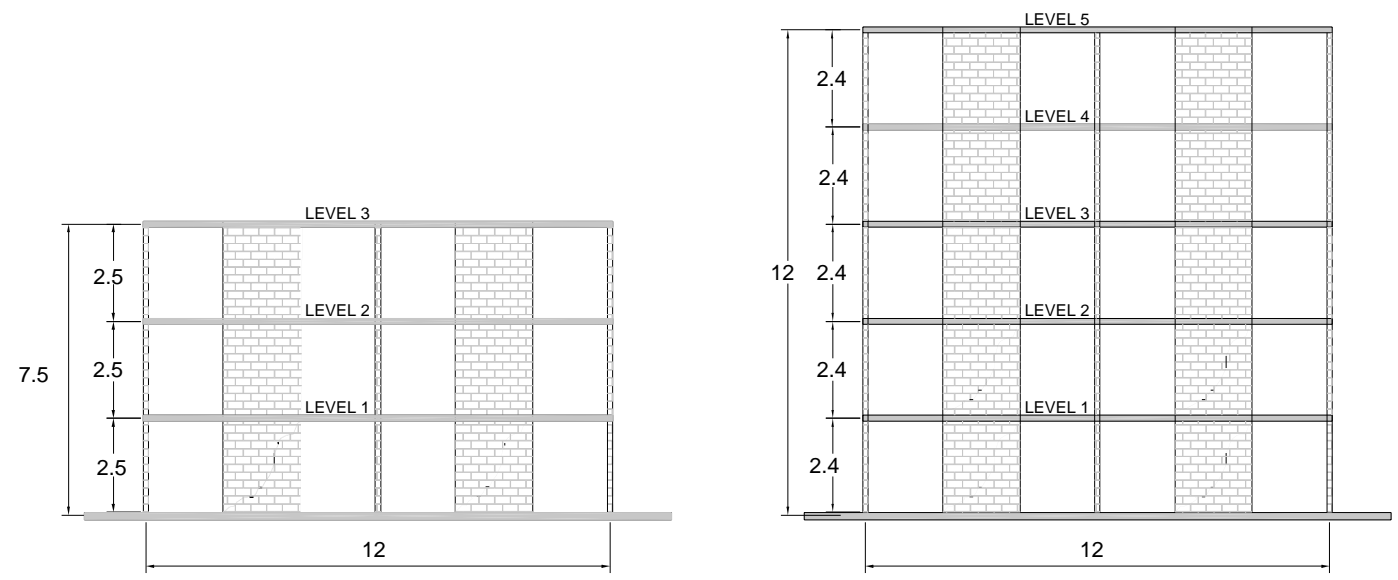

Fig. (5). Elevation of walls running in the horizontal direction for partially cracked response (dimensions in meters).
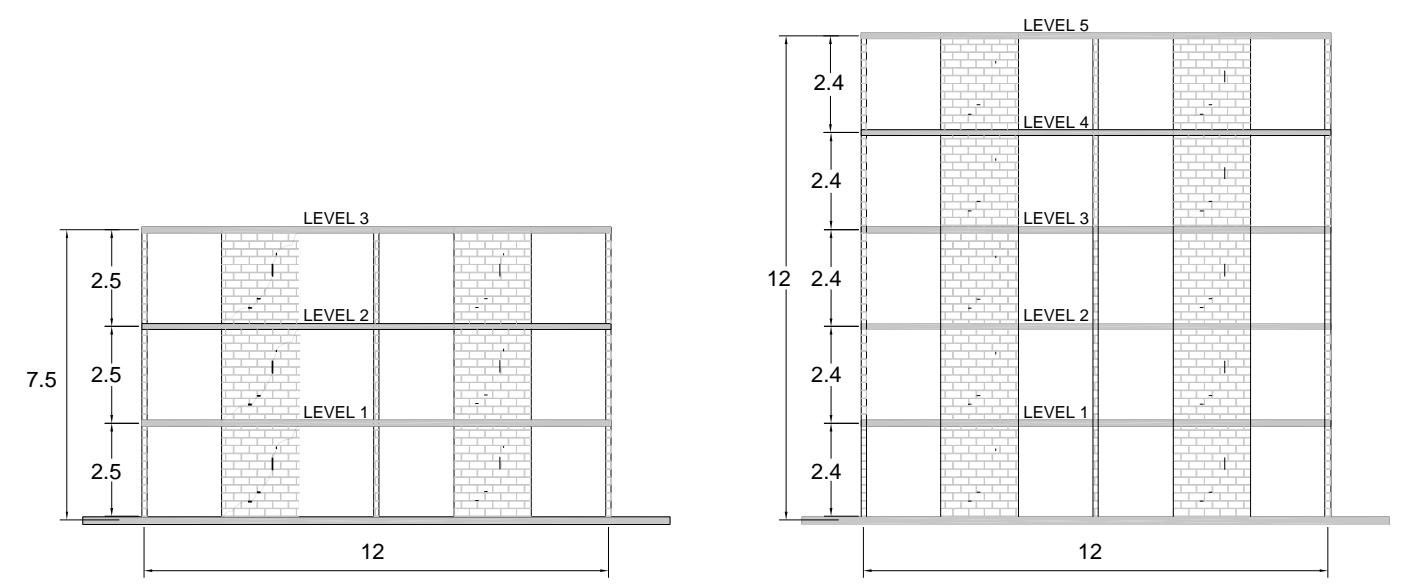

Fig. (6). Elevation of walls running in the horizontal direction for total cracked response (dimensions in meters).

walls of symmetric buildings, which are the critical ones for seismic design. In general, the proposed $F_{A E}, F_{A E P A}$ and $F_{A E T A}$, while relatively simple, are successful enough to improve the estimates using the SMSA (have a good correla- tion with a conventional 3D static analysis) for an important range of wall aspect ratios $(\mathrm{H} / \mathrm{L})$ for both central walls and perimeter walls $[25,29,30]$. 
It is worth noting that the proposed equations for elastic response $\left(\mathrm{F}_{\mathrm{AE}}\right.$, equations 5 and 6$)$ and partially nonlinear (cracked) response along the height $\left(\mathrm{F}_{\mathrm{AEPA}}\right.$, equation 7$)$ are now included in the guidelines for the seismic design of building structures of the updated Manual of Civil Structures [28,31], a model seismic code of Mexico.

The proposed $F_{A E P A}$ and $F_{A E T A}$ allow the use of the SMSA to estimate expected shear force demands when cracked response is expected, then extending the use of the SMSA of the Mexican codes towards performance-based design goals. Nevertheless, to complete the picture, it was equally important to conduct a comprehensive parametric study to assess the limiting value for the static eccentricity $\left(e_{s}\right)$ that must be allowed to use the SMSA for the described structural performance levels previously described (Figs. 3 to 6), as reported in detail in López-Blancas [32] and summarized in the following section.

\section{ASSESSMENT OF THE LIMITING VALUE FOR THE STATIC ECCENTRICITY}

\section{Generalities of the Parametric Study}

For the parametric study, a set of simple yet representative building models of three and five stories that comply with all the requirements of the SMSA were used. The typical symmetric plan of such models is depicted in Fig. (7), where the typical story height is 2.4 and $2.5 \mathrm{~m}$. All walls were supposed to be built with confined masonry made with fired clay bricks with thickness $t=12.5 \mathrm{~cm}$ (5 in), elastic modulus of the masonry $E=24,000 \mathrm{~kg} / \mathrm{cm}^{2}(2,400 \mathrm{MPa})$ and Poisson's ratio of the masonry $\mathrm{v}=0.25$.

Among other assumptions, the parametric study considered the following:

(1) Walls type 3 and 4 remain elastic and with a constant aspect ratio $\mathrm{H} / \mathrm{L}=1$, as the parametric study was based on the walls running in the horizontal direction (walls type 1 and 2). The properties of perimeter (PW) walls type 1 and central walls $(\mathrm{CW})$ type 2 varied from model to model, particularly in terms of the aspect ratio H/L, as identified in Table 1.

(2) For simplicity, the static eccentricity in plan $\left(e_{s}\right)$ was set from the eccentric position of the center of mass (CM) along the $\mathrm{Y}$ axis direction, as schematically depicted in Fig. (7). The position of all walls in plan was always symmetric. This simplification is valid because the results of the SMSA are compared with the results of an equivalent 3D static analysis. Results of static eccentricities in the superstructure of $0.05 \mathrm{~L}(5 \%), 0.075 \mathrm{~L}(7.5 \%)$, $0.10 \mathrm{~L}(10 \%)$ and $0.20 \mathrm{~L}(20 \%)$ the floor plan dimension ( $\mathrm{L}=12 \mathrm{~m}$ or $\mathrm{L}=39.4 \mathrm{ft}$ ) were evaluated.

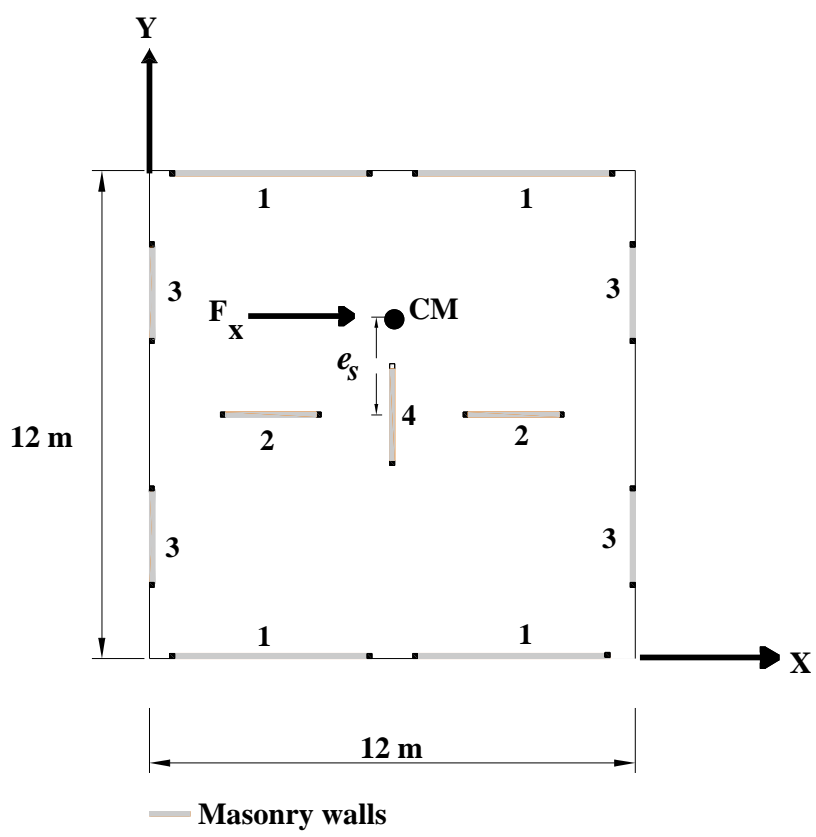

Fig. (7). Typical plan for the bearing wall building models.

(3) All models were studied using the SMSA and 3D static analyses considering three different performance levels for the structure: (a) elastic response, (b) completely nonlinear (cracked) response of all walls along the building height and, (c) partially nonlinear (cracked) response along the height. For the SMSA, the effective shear area factors proposed by NTCM-2004 (Eqs. 3 and 4) and by Tena-Colunga and Cano-Licona (Eqs. 5 to 8) were used accordingly for the structural performance under study. For 3D static analyses, walls were modeled with equivalent wide column analogies, as described in detail elsewhere [25]. For elastic response, shear deformations according to a classical Timoshenko beam theory were included. For cracked response, the equivalent cracked wide column analogy (Fig. 8) proposed by Bazán and Meli $[23,25,33]$ from the analysis of experimental data of

Table 1. Models for the Parametric Study for Each Structural Performance and Building Height

\begin{tabular}{|c|c|c|c|}
\hline Case Study & Total Number of Models & Aspect Ratio H/L for Central Walls (CW) Type 2 & Aspect Ratios H/L for Perimeter Walls (PW) Type 1 \\
\hline \hline 1 & 21 & 0.5 & 0.5 to 2.5 (0.1 increments) \\
\hline 2 & 21 & 1.0 & 0.5 to 2.5 (0.1 increments) \\
\hline 3 & 21 & 1.5 & 0.5 to 2.5 (0.1 increments) \\
\hline 4 & 21 & 2.0 & 0.5 to $2.5(0.1$ increments $)$ \\
\hline 5 & 21 & 2.5 & 0.5 to $2.5(0.1$ increments $)$ \\
\hline
\end{tabular}


several confined masonry walls designed according to the Mexican practice was used, given by the following equations:

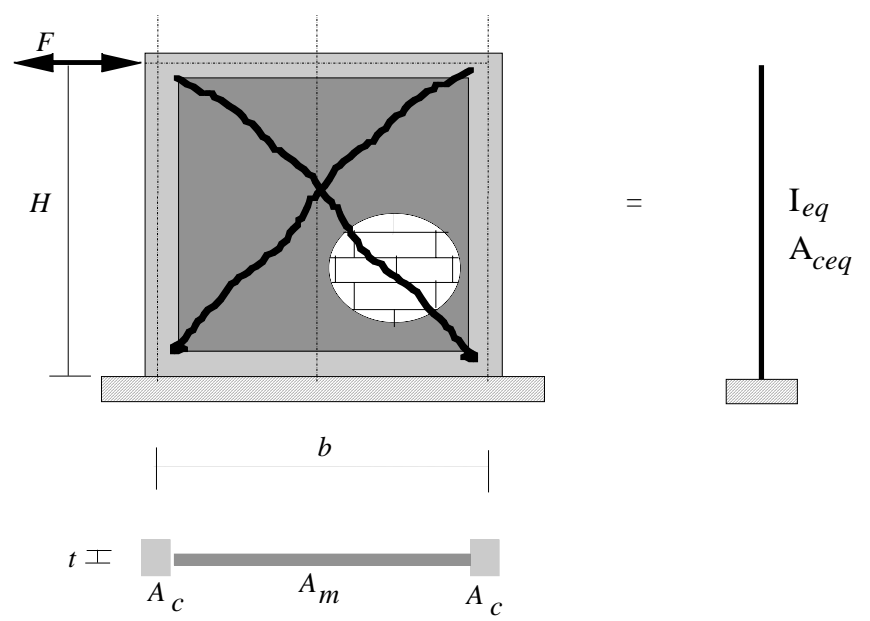

Fig. (8). Equivalent cracked wide column analogy proposed by Bazán and Meli.

$$
\begin{aligned}
& I_{e q}=A_{c} \frac{b^{2}}{2} \\
& A_{c e q}=(0.37-0.12 \zeta+0.023 \lambda)\left(A_{m}+2 A_{c}\right) \\
& \zeta=\frac{b}{H} \\
& \lambda=\frac{E_{c} A_{c}}{G_{m} A_{m}}
\end{aligned}
$$

where $I_{e q}$ is the equivalent cracked moment of inertia, $A_{c e q}$ is the equivalent cracked area, $A_{c}$ is the area of the confining vertical element, $A_{m}$ is the area of the masonry, $E_{c}$ is the elastic modulus of the concrete of the confining elements, $G_{m}$ is the shear modulus of the masonry, $\zeta$ is an aspect ratio parameter valid for the following range: $0.75 \leq \zeta \leq 2.5$, and $\lambda$ is a parameter that measures the relative axial stiffness of the confining elements with the shear stiffness of the masonry and is valid for the following range: $0.9 \leq \lambda \leq 11$. The equivalent cracked wide column analogy proposed by Bazán and Meli has also been reviewed with the experimental data of confined masonry walls and buildings tested in Mexico from 1990 to 2007 and found to be in good agreement as well [33].

It can be observed from Table 1 that five different wall aspect ratios (H/L) for the central walls (CW) type 2 and 21 different aspect ratios for the perimeter walls (PW) type 1 for each aspect ratio of the central wall are considered in the parametric study. Therefore, 105 different models were studied for each building height (3 and 5 stories), considered structural performance (elastic, partially cracked and completely cracked) and static eccentricities (5\%, 7.5\%, 10\% and $20 \%$ ), giving then a total of 2,520 different building models that were studied using both the SMSA and a equivalent 3D static analyses.
In this research, acting shear forces in shear walls according to the SMSA are compared with respect to those obtained with 3D static analysis for each building height, considered structural performance and static eccentricity. Usually, the critical story for design under lateral earthquake loading is the first story. Therefore, the first story was monitored to assess the differences in the acting story shear forces in walls of buildings when computed with the SMSA $\left(\mathrm{V}_{\mathrm{SMSA}}\right)$ with respect to those computed with 3D static analysis of asymmetric buildings where walls are modeled as equivalent wide columns $\left(\mathrm{V}_{3 \mathrm{D}}\right)$, through the $\mathrm{V}_{3 \mathrm{D}} / \mathrm{V}_{\mathrm{SMSA}}$ ratio.

Therefore, the key parameter considered in the study to define a limiting $e_{s}$ value is that the underestimation of $\mathrm{V}_{\text {SMSA }}$ for critical walls at the first story should not be large when compared to those shear forces obtained from 3D linear static analyses $\left(\mathrm{V}_{3 \mathrm{D}}\right)$ of such buildings, then allowing to achieve reasonable safe designs for the subject masonry structures.

The shear strength of masonry in Mexico is low because the mechanical properties of bricks and blocks are low compared to US standards. Therefore, from this perspective, an inaccurate estimate of design shear may have a negative impact in the expected structural performance of confined masonry structures designed with the SMSA. Nevertheless, it is also known that lowrise confined masonry structures may develop significant overstrength, a fact that has been recently confirmed experimentally in shaking table tests [34]. For these reasons, it was proposed to accept a maximum underestimation of $40 \%$ of shear force computed with the simplified method with respect to the one obtained from a 3D static analysis, that is, $\mathrm{V}_{3 \mathrm{D}} / \mathrm{V}_{\mathrm{SMSA}} \leq 1.4$. This proposed value takes into account essentially the following aspects: (a) the low design shear strength $\left(v_{m}^{*}\right)$ for the Mexican masonry, where a $40 \%$ difference may require to use stronger units and/or mortar, or to require horizontal steel reinforcement, (b) because of the typification of wall sections, confined masonry structures designed according to the Mexican code [21,22] may develop an important overstrength [34], (c) the SMSA accounts for bidirectional seismic effects approximately and indirectly through the design seismic coefficient established by the method and, (d) the SMSA does not amplify forces due to torsional effects, including accidental eccentricities and dynamic effects, something that it is requested by NTCS-2004 for structures designed with static and dynamic methods of analyses.

The results of the described parametric study are reported in detail elsewhere [32] and briefly discussed in following sections. The most interesting results to discuss for practical purposes are shown in Figs. (9 to 13), which are those related to the value for $e_{s}$ that must be allowed for the SMSA for the structural performance under study.

It is worth noting that in Figs. (9 to 13), the results for the first story walls are plotted for all cases of study identified in Table 1. In these figures, open symbols connected with continuous lines are used to depict the results of the central walls $(\mathrm{CW})$, whereas the corresponding full symbols connected with broken lines are used to depict the results for the 
critical perimeter walls (PW). For instance, when the aspect ratio of the central walls is fixed for $\mathrm{H} / \mathrm{L}=1$, for the entire range of aspect ratios $\mathrm{H} / \mathrm{L}$ considered for the perimeter walls, open square symbols are used to depict the $\mathrm{V}_{3 \mathrm{D}} / \mathrm{V}_{\text {SMSA }}$ ratios for the first story central walls $(\mathrm{CW})$ whereas full square symbols are used to depict the $\mathrm{V}_{3 \mathrm{D}} / \mathrm{V}_{\mathrm{SMSA}}$ ratios for the critical first story perimeter walls (PW).

\section{Assessment of $e_{s}$ for Elastic Response}

The $\mathrm{V}_{3 \mathrm{D}} / \mathrm{V}_{\text {SMSA }}$ ratios for the first story walls of 3 and 5 story asymmetric models with $e_{s}=5 \%$ are presented in Fig. (9) when the behavior of the walls for the $3 \mathrm{D}$ analyses is elastic (Fig. 4) and the effective shear area factors proposed by Tena-Colunga and Cano-Licona (Equations 5 and 6) are used in the SMSA.

It can be concluded from the observation of these figures that approximations obtained with the SMSA using the proposed effective shear area factors for elastic response are not good enough even for this small eccentricity of $5 \%$. When the central walls are wide $(H / L \leq 1)$, the shear forces of the critical perimeter walls (PW) are substantially underestimated, particularly for the aspect ratio range: $1.5 \leq \mathrm{H} / \mathrm{L} \leq 2.5$. When the central walls are slender $(\mathrm{H} / \mathrm{L} \geq 1.5)$, the corresponding shear forces are considerably underestimated for the following aspect ratio range of the perimeter walls: $0.5 \leq \mathrm{H} / \mathrm{L} \leq 1.5$.

Therefore, it can be concluded that no eccentricity or a static eccentricity smaller than $5 \%$ should be allowed for the SMSA when considering elastic response of shear masonry walls.

\section{Assessment of $e_{s}$ for Current $\mathrm{F}_{\mathrm{AE}}$ of NTCM-2004}

According to NTCM-2004, a degree of nonlinear response (cracking) is allowed in confined masonry structures to survive the design earthquake, as schematically depicted in Fig. (5). Therefore, in order to assess the value of $e_{s}$ that

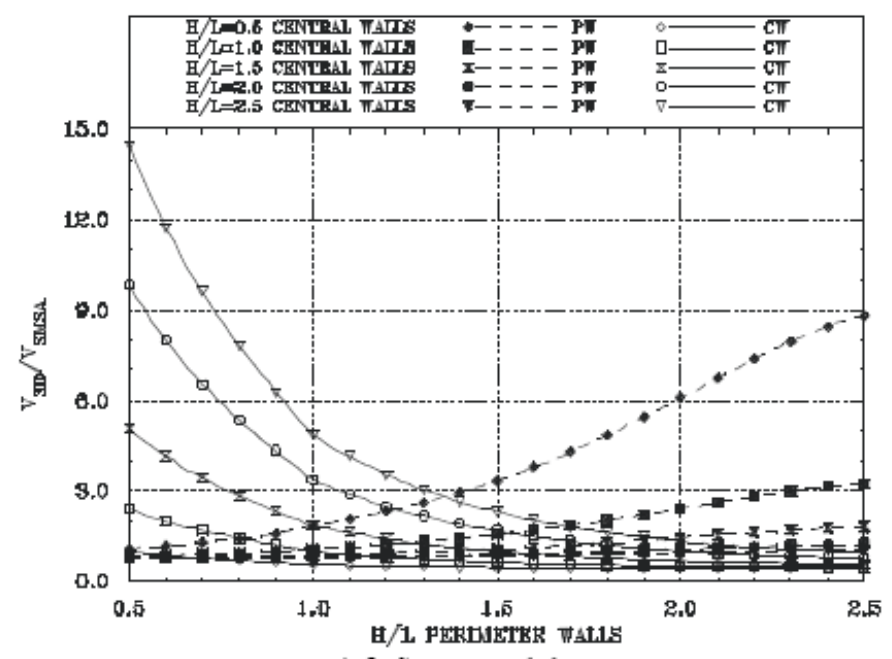

a) 3-Story models should be allowed for the SMSA as presented in NTCM2004 , the referred damage state is the one that should be considered in the parametric studies.

Then, the $\mathrm{V}_{3 \mathrm{D}} / \mathrm{V}_{\mathrm{SMSA}}$ ratios for the first story walls of 3 and 5 story asymmetric models with $e_{s}=5 \%$ are presented in Fig. (10) when the behavior of the walls for the 3D static analyses is the partially cracked response expected for confined masonry buildings (Fig. 5) and the effective shear area factors proposed by NTCM-2004 (Equations 3 and 4) are used in the SMSA.

It can be observed that the results obtained for 3-story (Fig. 10a) and 5-story (Fig. 10b) models are somewhat contrasting for the reasons given in the last paragraph of this section. According to the results obtained for 3-story models, the approximation obtained with the SMSA is poor and unsafe for some of the perimeter and central walls for $e_{s}=5 \%$, particularly: (a) perimeter walls (PW) with aspect ratios in the range $1.7 \leq \mathrm{H} / \mathrm{L} \leq 2.5$ when aspect ratios of the central walls are in the range $0.5 \leq \mathrm{H} / \mathrm{L} \leq 1.5$ and, (b) central walls $(\mathrm{CW})$ with aspect ratios in the range $2.0 \leq \mathrm{H} / \mathrm{L} \leq 2.5$ when aspect ratios of the perimeter walls are in the range $0.5 \leq \mathrm{H} / \mathrm{L} \leq 1.5$. In contrast, the approximation obtained with the SMSA for 5 -story models is reasonably good and safe for $e_{s}=5 \%$ for all aspect ratios of the central and perimeter walls considered, except perhaps for slender central walls with $\mathrm{H} / \mathrm{L}=2.5$ when the perimeter walls are within the following aspect ratio range: $1.2 \leq \mathrm{H} / \mathrm{L} \leq 1.6$.

Therefore, it can be concluded based primarily on the results of 5-story models that for practical purposes, a static eccentricity $e_{s}$ up to $5 \%$ could be allowed for the use of the SMSA as addressed in NTCM-2004, instead of $e_{s}=10 \%$ currently allowed in this code.

It is worth noting that the described discrepancies for 3story and 5-story models were expected from the analysis of results obtained in previous studies with symmetric systems [29]. The impact of shear deformations for the second story

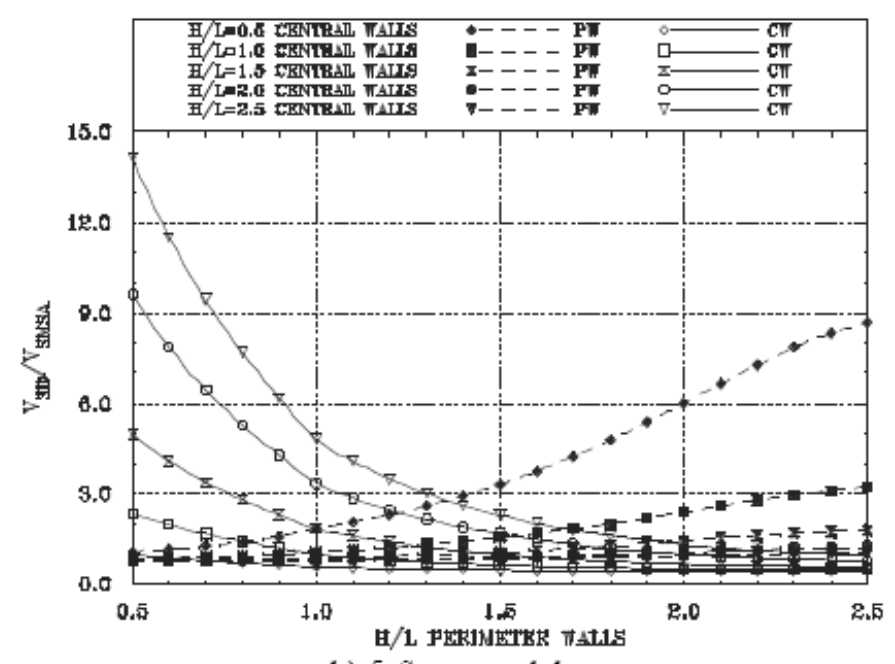

b) 5 -Story models

Fig. (9). $\mathrm{V}_{3 \mathrm{D}} / \mathrm{V}_{\mathrm{SMSA}}$ ratios for asymmetric shear wall buildings $\left(e_{s}=0.05 \mathrm{~L}=5 \%\right)$ for elastic behavior using proposed $\mathrm{F}_{\mathrm{AE}}$ for the SMSA when subjected to unidirectional static lateral loads. 


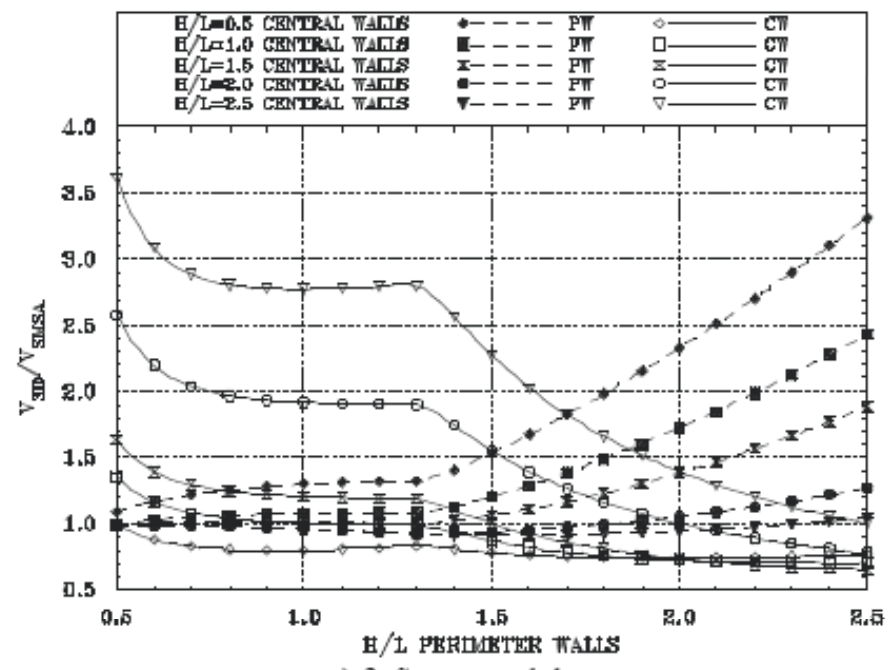

a) 3-Story models

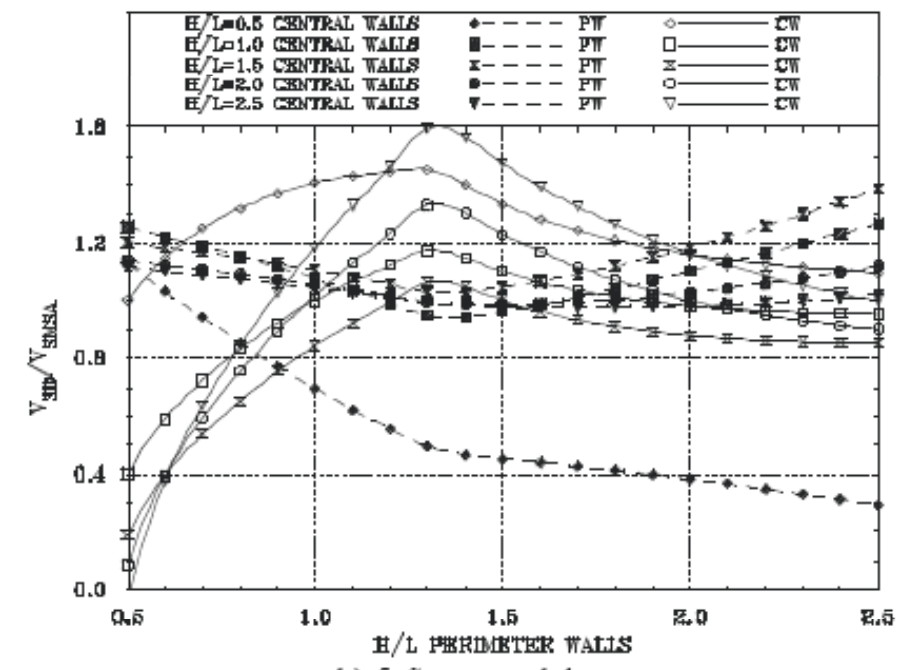

b) 5-Story models

Fig. (10). $\mathrm{V}_{3 \mathrm{D}} / \mathrm{V}_{\mathrm{SMSA}}$ ratios for asymmetric shear wall buildings $\left(e_{s}=0.05 \mathrm{~L}=5 \%\right)$ for partially cracked response using $\mathrm{F}_{\mathrm{AE}}$ of $\mathrm{NTCM}-2004$ for the SMSA when subjected to unidirectional static lateral loads.

walls for 3-story models is much more important than for 5story models, as the second story walls for the 3-story models are much stiffer than for the 5-story models. In 3-story models, the second story walls are elastic and therefore they have a $100 \%$ effective shear area, they are stiffer and shear deformations are the dominant mode of response, particularly for long walls. In contrast, in 5-story models the second story walls are already cracked (Fig. 5) and their effective moment of inertia and shear area are considerably reduced (Eqs. 9 and 10), then they are more flexible and flexural deformations are more important than shear deformations, particularly for slender walls.

As discussed in previous studies [25], the effective shear area factors proposed in Mexican codes since the 1980s (Eqs. 3 and 4) were based upon experts' opinion of code

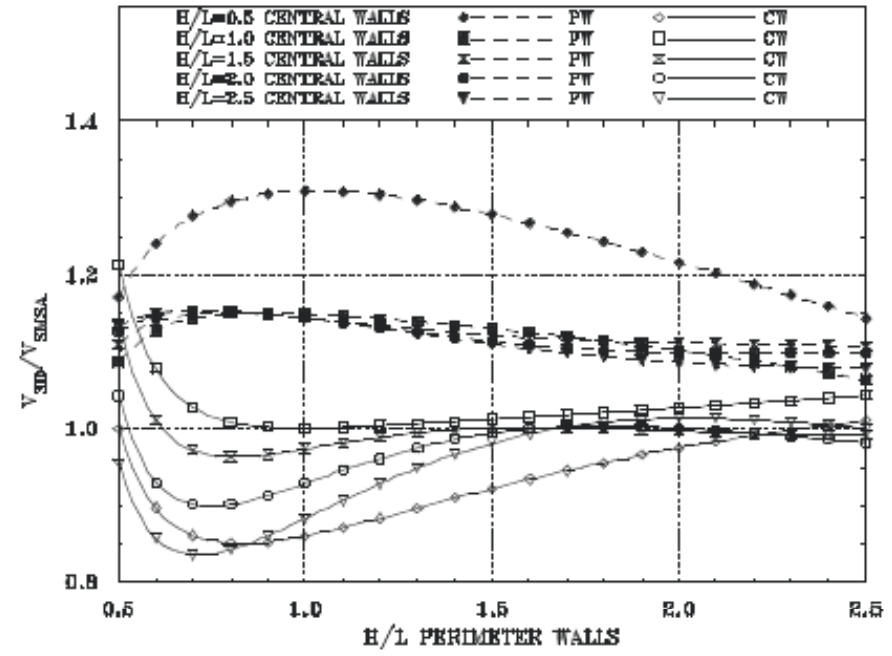

a) 3-Story models committee members and, therefore, they were not calibrated for the described structural performance.

\section{Assessment of $e_{s}$ for Partially Cracked Response}

The $\mathrm{V}_{3 \mathrm{D}} / \mathrm{V}_{\mathrm{SMSA}}$ ratios for the first story walls of 3 and 5 story asymmetric models with $e_{s}=10 \%$ are presented in Fig. (11) when the behavior of the walls for the 3D static analyses is the partially cracked response expected for confined masonry walls (Fig. 5) and the effective shear area factor proposed by Tena-Colunga and Cano-Licona (Equation 7) and currently included in MOC-2008 is used in the SMSA.

It can be observed from Fig. (11) that, in general, better approximations are obtained for 3-story models than for 5story models. Worst approximations are obtained for the

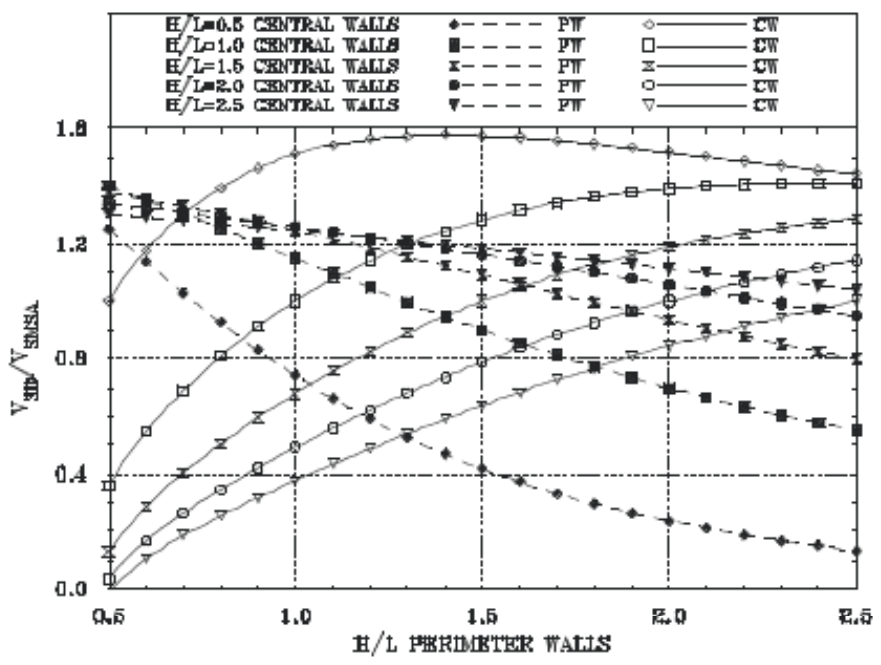

b) 5 -Story models

Fig. (11). $\mathrm{V}_{3 \mathrm{D}} / \mathrm{V}_{\mathrm{SMSA}}$ ratios for asymmetric shear wall buildings $\left(e_{s}=0.10 \mathrm{~L}=10 \%\right)$ for partially cracked response using proposed $\mathrm{F}_{\mathrm{AEPA}}$ for the SMSA when subjected to unidirectional static lateral loads. 
central walls $(\mathrm{CW})$ of 5-story models when their aspect ratio is $\mathrm{H} / \mathrm{L}=0.5$ and the aspect ratios of the perimeter walls are in the range $0.9 \leq \mathrm{H} / \mathrm{L} \leq 2.2$ (Fig. 11b). It is worth noting that the differences in the shapes of the curves obtained for 3-story and 5-story models are also due to the different impact of shear deformations because the second story walls are modeled elastic in the 3 -story models and cracked in the 5-story models (Fig. 5).

It can be concluded from the results presented in Fig. (11) that, for practical purposes, using the proposed effective shear area factor in the SMSA leads to reasonably safe predictions of the acting shear in the first story walls for eccentricities up to $10 \%$. In fact, this is the static eccentricity that it is allowed for the SMSA and this effective shear area factor in MOC-2008 [31].

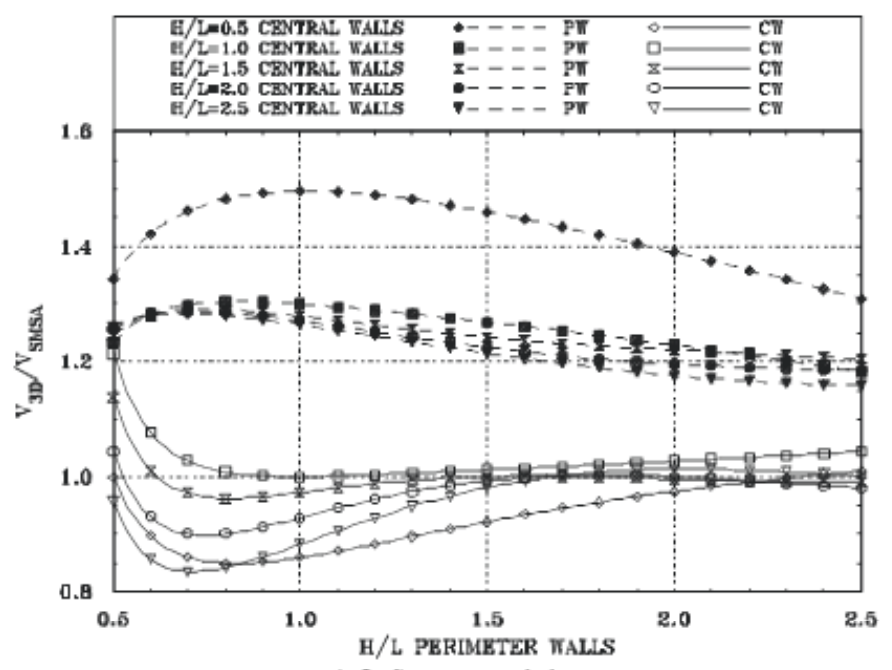

a) 3-Story models
According to Mexican seismic codes [26-28,31] a building is considered torsionally irregular in terms of a static eccentricity greater than 10 percent of the plan dimension in the given direction of analysis $\left(e_{s}>0.10 \mathrm{~L}\right)$. In fact, a strong torsional irregularity is defined in terms of a static eccentricity greater than 20 percent $[26,28,31]$. It is worth noting that the results obtained for $e_{s}=20 \%$, particularly for the 5-story models (Fig. 12), mostly confirmed that the SMSA should not be allowed for the design of low-rise masonry shear wall buildings with such a large static eccentricity.

\section{Assessment of $e_{s}$ for Totally Cracked Response}

The $\mathrm{V}_{3 \mathrm{D}} / \mathrm{V}_{\text {SMSA }}$ ratios for the first story walls of 3 and 5 story asymmetric models with $e_{s}=10 \%$ are presented in Fig. (13) when the behavior of the walls for the 3D static analy-

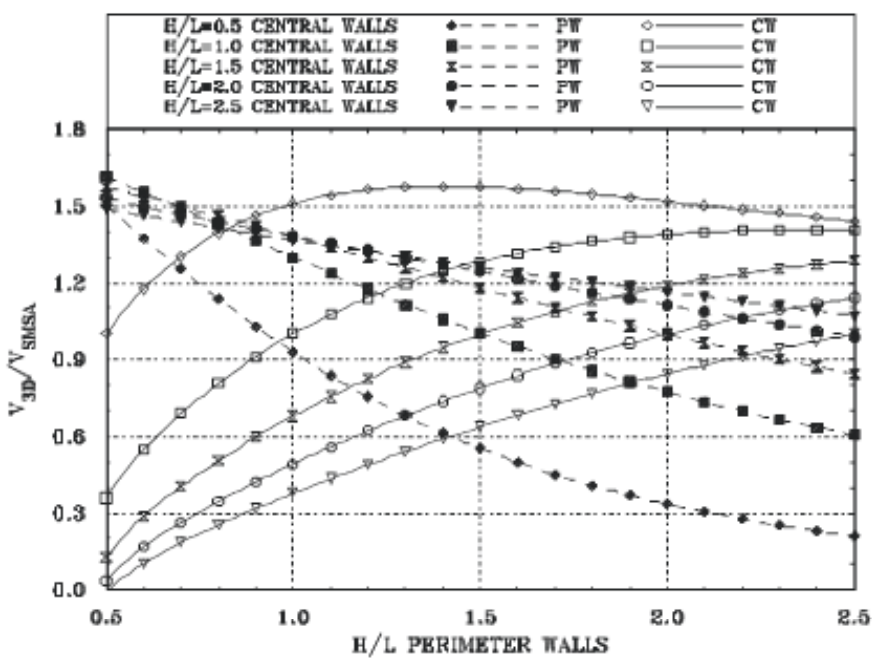

b) 5-Story models

Fig. (12). $\mathrm{V}_{3 \mathrm{D}} / \mathrm{V}_{\mathrm{SMSA}}$ ratios for asymmetric shear wall buildings $\left(e_{s}=0.20 \mathrm{~L}=20 \%\right)$ for partially cracked response using proposed $\mathrm{F}_{\mathrm{AEPA}}$ for the SMSA when subjected to unidirectional static lateral loads.

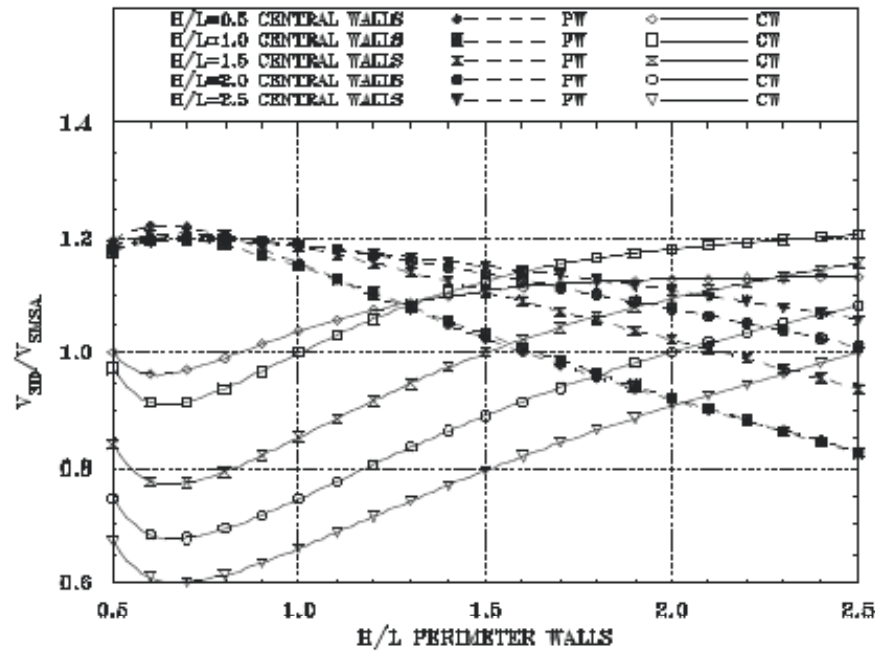

a) 3-Story models

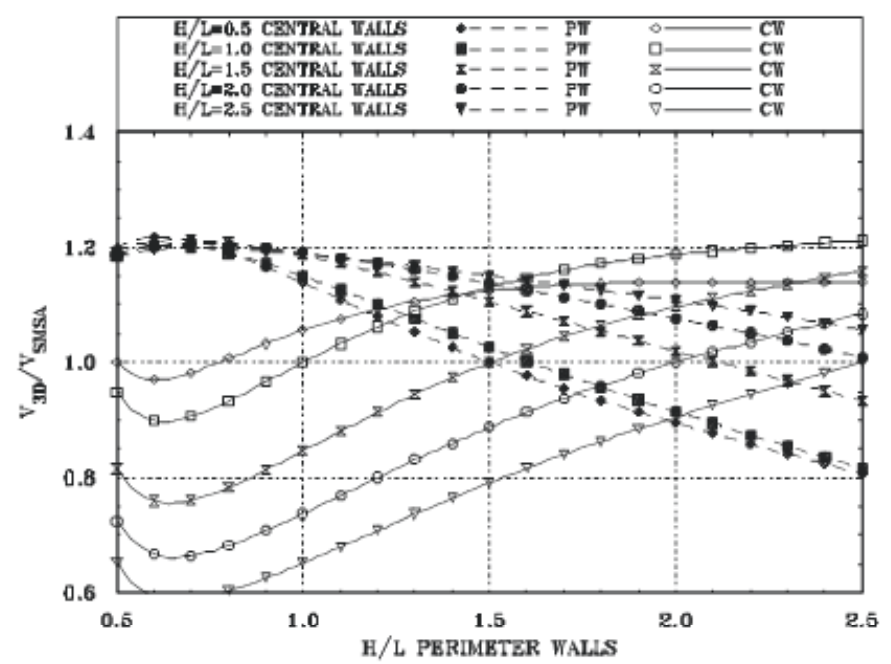

b) 5-Story models

Fig. (13). $\mathrm{V}_{3 \mathrm{D}} / \mathrm{V}_{\mathrm{SMSA}}$ ratios for asymmetric shear wall buildings $\left(e_{s}=0.10 \mathrm{~L}=10 \%\right)$ for totally cracked response using proposed $\mathrm{F}_{\mathrm{AETA}}$ for the SMSA when subjected to unidirectional static lateral loads. 
ses is the totally cracked response expected for unconfined and unreinforced masonry walls as defined by NTCM-2004 (Fig. 6) and the effective shear area factor proposed by TenaColunga and Cano-Licona (Eq. 8), which were derived from the stiffness of cracked confined masonry walls proposed by Bazán and Meli (Eqs. 9 to 12). It is worth noting that, according to NTCM-2004 [21,22], an unconfined and unreinforced masonry wall is not a plain, completely unreinforced masonry wall, but a wall that has a minimum confinement (reinforcement) for structural integrity, which is below the minimum requirements and standards set by code for confined masonry and for reinforced masonry walls. Therefore, it is also worth noting that the results obtained under such modeling constitute an approximation, as they do not fully represent the cracked response for partially confined or unconfined masonry walls as defined in NTCM-2004 (no experimental information available yet).

It can be observed from the results presented in Fig. (13) that approximations for this structural performance are reasonable enough for practical purposes (underestimations up to $20 \%$ ). Then, the proposed effective shear area factor for totally cracked response could be used for safe predictions of the acting shear in the first story walls for eccentricities up to $10 \%$. Therefore, the authors suggest to limit $e_{s}=10 \%$ for unconfined and unreinforced masonry construction, a limit that it is also in agreement with the definition of torsional irregularities of Mexican seismic codes, as described in the previous section.

\section{CONCLUDING REMARKS}

In this paper, a parametric study devoted to assess the limiting value for the static eccentricity $\left(e_{s}\right)$ for the application of the simplified method for seismic analysis (SMSA) of bearing-wall confined masonry structures of Mexican Building Codes was presented. The criterion used to propose limiting values for $e_{s}$ was that the underestimation of shear forces predicted for critical first-story walls with the SMSA was within reasonable limits with respect to those shear forces computed with rigorous methods of analysis, in order to insure reasonably safe designs of such structures. Three different performance levels for the structure were evaluated: (a) elastic response, (b) completely nonlinear (cracked) response of all walls along the building height and, (c) partially nonlinear (cracked) response along the height. The proposal for the SMSA of current NTCM-2004 and MOC2008 Mexican codes for confined masonry structures under the design earthquake scenario were evaluated.

Based upon the results of the described parametric study, the following limiting values for the computed static eccentricity $e_{s}$ are proposed for the use of the SMSA:

a. $e_{s}$ up to $5 \%$ for partially nonlinear (cracked) response along the height and using the effective shear area factors proposed by NTCM-2004 (Eqs. 3 and 4) for the collapse prevention performance level of confined masonry bearing wall structures under the maximum credible earthquake scenario. b. $e_{s}$ up to $10 \%$ for partially nonlinear (cracked) response along the height and using the effective shear area factor proposed by MOC-2008 (Eq. 7) for the collapse prevention performance level of confined masonry bearing wall structures under the maximum credible earthquake scenario.

c. $e_{s}$ up to $10 \%$ for totally nonlinear (cracked) response along the height and using the effective shear area factors proposed by Tena-Colunga and Cano-Licona (Eq. 8) for the collapse prevention performance level of unconfined and unreinforced masonry bearing wall structures under the maximum credible earthquake scenario.

d. For elastic response (Eqs. 5 and 6), no eccentricity or a static eccentricity $e_{s}$ smaller than 5\% should be allowed for the fully operational performance level of all masonry bearing wall structures under the service earthquake scenario. However, the most adequate limiting value for this structural performance should be discussed by code committees, as it is of interest for the following design scenarios: (1) to review the design of conventional masonry shear wall structures under the service earthquake and, (2) to design base-isolated masonry shear wall structures under the maximum credible earthquake.

Finally, it can be commented that depending on the discussion of NTCM code committee members, the effective shear area factors of NTCM-2004 given by Eqs. 3 and 4 most likely are going to be substituted by those proposed in previous studies (Eqs. 5 to 8 ) in the next review of the masonry regulations of Mexico's Federal District Code.

\section{ACKNOWLEDGEMENT}

The MSc. fellowship granted to Arturo López-Blancas by the National Science and Technology Council of Mexico (Conacyt) is gratefully acknowledged.

\section{REFERENCES}

[1] R. Meli, "Structural design of masonry buildings: The Mexican practice," In: ACI Special Publication 147 Masonry in the Americas, American Concrete Institute, 1994, pp. 239-262.

[2] S. M. Alcocer, and R. E. Klingner, "Masonry research in the Americas," In: ACI Special Publication 147 Masonry in the Americas, American Concrete Institute, 1994, pp. 127-169.

[3] EERI/IAEE, World Housing Encyclopedia, Earthquake Engineering Research Institute and the International Association for Earthquake Engineering, 2010. Available: www.worldhousing.net

[4] H. Gallegos, "Masonry in Peru," In ACI Special Publication 147 Masonry in the Americas, American Concrete Institute, 1994, pp. 307-331.

[5] P. Hidalgo, "Seismic behavior and earthquake-resistant design of masonry buildings in Chile," In ACI Special Publication 147 Masonry in the Americas, American Concrete Institute, 1994, pp. 333-350.

[6] L. García, and L. Yamín, "Review of masonry construction in Colombia," In: ACI Special Publication 147 Masonry in the Americas, American Concrete Institute, 1994, pp. 283-305.

[7] M. Tomazevic, Earthquake-Resistant Design Of Masonry Buildings, London: Imperial College Press, 1999.

[8] D. D’Ayala, M. Bostenaru, A. Goretti, A. Yakut and M. Tomazevic, "Application of the World housing encyclopedia", Geophysical Research Abstracts, vol. 7, 2005.

[9] M. El-Gawady, P. Lestuzzi and M. Badoux, "A review of conventional seismic retrofitting techniques for URM," In: $13^{\text {th }}$ Interna- 
tional Brick and Block Masonry Conference, Amsterdam, the Netherlands, CD-ROM, July 2004.

[10] T. Boen, and K. S. Privadi, "Engineering the non-engineered houses for better earthquake resistance in Indonesia," In: $D R H-$ Asia Content Meeting, Kobe, Japan, pp. 206-208, March 2007.

[11] ERRA, "Reconstruction of houses in earthquake affected areas. Single storey construction compliance catalogue," in Earthquake Reconstruction and Rehabilitation Authority, National Engineering Services, Lahore, Pakistan, May 2007. Available http://www. nespak.com.pk

[12] N. Hori, N. Inoue, D. Purushotam, T. Nishida, and J. Kobayashi, "Experimental and analytical studies on earthquake resisting behaviour of confined concrete block masonry structures", Earthquake Engineering and Structural Dynamics, vol. 35, pp. 1699-1719, 2006.

[13] RPA-99, "Regles Parasismiques Algeriennes RPA 99/Version 2003," in Document Technique Reglementaire DTR-B-C-2-48, Ministere de L'Habitat ed de L'Urbanisme, Algeria, 2003. (in French)

[14] ASCE 7-05, "Minimum design loads for buildings and other structures," In: ASCE Standard ASCE/SEI 7-05, American Society of Civil Engineers, 2005.

[15] A. Tena-Colunga, and D. P. Abrams, "Response of an unreinforced masonry building during the Loma Prieta Earthquake," In: Structural Research Series No. 576, Department of Civil Engineering, University of Illinois at Urbana-Champaign, December 1992.

[16] Tena-Colunga, and D. P. Abrams, "Seismic behavior of structures with flexible diaphragms", ASCE Journal of Structural Engineering, vol. 122, no. 4, pp. 439-445, 1996.

[17] K. A. T. Tokoro, J. C. Anderson and V. V. Bertero, "Seismic performance of masonry buildings and design implications," in Report PEER 2004/01, Pacific Earthquake Engineering Center, February 2004.

[18] G. L. Cohen, R. E. Klingner, J. R. Hayes and S. Sweeney, "Seismic response of low-rise masonry buildings with flexible roof diaphragms: iii. synthesis and application", Earthquake Spectra, vol. 22, no. 2, pp. 329-347, 2006.

[19] S.-C. Kim, and D. W. White, "Nonlinear analysis of a one-story low-rise masonry building with flexible diaphragm subjected to seismic excitation", Engineering Structures, vol. 26, no. 14, pp. 2053-2067, 2004.

[20] Eurocode 8, "Eurocode 8: Design of structures for earthquake resistance - Part 1: General rules, seismic actions and rules for buildings," in European Standard EN 1998-1:2004, European Committee for Standardization, Brussels, April 2004.

[21] NTCM-2004, "Normas Técnicas Complementarias para Diseño y Construcción de Estructuras de Mampostería", Gaceta Oficial del Distrito Federal, October 2004. (in Spanish).
[22] NTCM-2004, "Complementary Technical Norms for Design and Construction of Masonry Structures of Mexico's Federal District Code, 2004 version," Translation to English, 2010. Available: http://www.confinedmasonry.org/existing-codes-and-standards

[23] E. Bazán, and R. Meli, Diseño sísmico de edificios, second edition, Limusa, México, 1999. (in Spanish).

[24] INPRES, "Normas Argentinas para Construcciones Sismorresistentes. Construcciones de Mamposteria," In: Reglamento INPRESCIRSOC 103, Sistema Reglamentario Argentino para las Obras Civiles, Buenos Aires, August 1991. (in Spanish).

[25] A. Tena-Colunga and J. Cano-Licona, "Simplified method for the seismic analysis of masonry shear-wall buildings", ASCE Journal of Structural Engineering, vol. 135, no. 5, pp. 511-520, 2010.

[26] NTCS-2004, "Normas Técnicas Complementarias para Diseño por Sismo," in Gaceta Oficial del Distrito Federal, October 2004. (in Spanish).

[27] A. Tena-Colunga, "International seismic zone tabulation proposed by the 1997 UBC code: Observations for Mexico", Earthquake Spectra, vol. 15, no. 2, pp. 331-360, May, 1999.

[28] A. Tena-Colunga, U. Mena-Hernández, L. E. Pérez-Rocha, J. Avilés, M. Ordaz, and J. I. Vilar, "Updated seismic design guidelines for buildings of a model code of Mexico", Earthquake Spectra, vol. 25, no. 4, pp. 869-898, November, 2009.

[29] J. Cano-Licona, "Propuesta de modificación al método simplificado de análisis sísmico de las Normas Técnicas Complementarias para Diseño y Construcción de Estructuras de Mampostería", M.S. Thesis, Universidad Nacional Autónoma de México, Mexico DF, Mexico, 2005, (in Spanish).

[30] J. Cano-Licona, and A. Tena Colunga, "Diseño sísmico de estructuras de mampostería para distintos niveles de desempeño estructural con base en adecuaciones propuestas al método simplificado de análisis", In XV Congreso Nacional de Ingeniería Sísmica, México, DF, CDROM, Paper No. X-01, pp. 1-20, September 2005, (in Spanish).

[31] MOC-2008, Manual de diseño de obras civiles. Diseño por sismo, Mexico: Comisión Federal de Electricidad, 2009, (in Spanish).

[32] A. López-Blancas, "Estudio de las limitantes por torsión impuestas al método simplificado de análisis de estructuras de mampostería", M.S. Thesis, Universidad Autónoma Metropolitana Azcapotzalco, Mexico DF, Mexico, 2007, (in Spanish).

[33] Tena-Colunga, A. Juárez-Ángeles, and V. M. Salinas-Vallejo, "Cyclic behavior of combined and confined masonry walls", Engineering Structures, vol. 31, no. 1, pp. 240-259, 2009.

[34] R. Barragán, J. G. Arias, and S. M. Alcocer, "Variation of dynamic properties of Mexican low-cost housing buildings with level of seismic motion," In: 14 ${ }^{\text {th }}$ World Conference on Earthquake Engineering, Beijing, China, Paper 12-01-0092, CD-ROM, October 2008.

(C) Tena-Colunga and López-Blancas; Licensee Bentham Open.

This is an open access article licensed under the terms of the Creative Commons Attribution Non-Commercial License (http://creativecommons.org/licenses/_by-nc/3.0/) which permits unrestricted, non-commercial use, distribution and reproduction in any medium, provided the work is properly cited. 